\title{
PERILAKU ASERTIF GENERASI MILENIAL DALAM PERSPEKTIF PSIKOLOGI ISLAM
}

\section{Sarlin Ampuno}

Alumni Universitas Islam Negeri Sunan Kalijaga

E-mail: sarlien16ampuno@gmail.com

\begin{abstract}
ABSTRACK
This study aims to further examine the millennial generation's assertive behavior from the perspective of Islamic psychology, using a literature study approach. The data obtained from books and journal articles related to assertive behavior, the millennial generation, and also Islamic psychology. The results of this study explain that in the perspective of Islamic psychology, assertive behavior requires individuals, especially the current millennial generation to express their voices. This includes assertiveness as a defense of personal rights, expressions of thoughts, feelings, and beliefs directly, honestly, and appropriate to respect the rights of others.
\end{abstract}

Keywords: Assertive Behavior, Millennial Generation, Islamic Psychology

\begin{abstract}
ABSTRAK
Penelitian ini bertujuan untuk mengkaji lebih lanjut terkait tentang perilaku asertif generasi milenial dalam perspektif psikologi Islam, dengan menggunakan pendekatan studi pustaka. Adapun data yang diperoleh bersumber dari buku-buku dan artikel jurnal yang terkait dengan perilaku asertif, generasi milenial dan juga psikologi Islam. Hasil kajian ini menjelaskan bahwa dalam perspektif psikologi Islam, perilaku asertif menuntut individu, khususnya generasi milenial saat ini agar tegas menyuarakan keinginan. Hal tersebut meliputi ketegasan sebagai pembelaan atas hak-hak pribadi, ekspresi pikiran, perasaan, dan keyakinan secara langsung, jujur, serta pantas untuk menghormati hak-hak orang lain.
\end{abstract}

Kata kunci: Perilaku Asertif, Generasi Milenial, Psikologi Islam

\section{PENDAHULUAN}

Di zaman modern seperti sekarang, banyak orang yang ingin pendapatnya didengar, baik itu sebuah opini, saran, bahkan kritikan dengan tanpa memikirkan perasaan atau tanggapan orang lain. Persoalan yang sering muncul adalah ketika seseorang cenderung tidak membentengi diri dengan perilaku asertif ketika berkomunikasi, di mana perilaku asertif sendiri memiliki arti kemampuan seseorang untuk mengkomunikasikan apa yang diinginkan, dirasakan, dan dipikirkan kepada orang lain namun dengan tetap menjaga dan menghargai hak-hak serta perasaan pihak lain atau pihak yang dituju, (Dewi \& Karlina, 2017) dengan kata lain, ketegasan sebagai pembelaan atas hak-hak pribadi dan ekspresi pikiran, perasaan, dan keyakinan secara langsung, jujur, serta pantas untuk menghormati hak orang lain. (Anastacio \& Zelia, 2016)

Dalam literatur lain mengatakan bahwa perilaku asertif adalah bagian dari keterampilan sosial. Orang yang asertif merasa nyaman saat mengungkapkan kebutuhannya dan membuat orang lain tetap merasa nyaman. Orang-orang yang asertif 
juga pada umumnya memiliki kecerdasan emosional yang baik, tahu alasan mengapa menolak atau menerima pernyataan orang lain, serta tahu akibat dan sebab sesuatu yang akan dilakukan. (Sriyanto, Abdulkarim, Zainul, \& Maryani, 2014)

Penelitian Johnson menunjukkan bahwa individu yang berperilaku asertif timbul karena adanya kebebasan emosi dan keadaan afektif yang mendukung dengan cara: (1) menyatakan hak-hak pribadi; (2) berbuat sesuatu untuk mendapatkan hak tersebut; (3) melakukan hal tersebut sebagai usaha untuk mencapai kebebasan emosi, sehingga seseorang tersebut mampu menyesuaikan diri (adaptive), lebih percaya diri, lebih kompeten, dapat diandalkan, (Suryanoto, 2015) lebih mampu bersikap positif, percaya terhadap orang lain, lebih objektif, dan terbuka. Sebaliknya individu yang kurang mampu dalam keterbukaan diri (self disclosure) atau tidak memiliki kemampuan asertif, maka individu tersebut tidak mampu menyesuaikan diri, kurang percaya diri, timbul perasaan takut, cemas, merasa rendah diri, serta tertutup, (Faisal, 2017) dan akhirnya membuat individu kesulitan beradaptasi dengan dunia luas saat ini, atau yang dikenal dengan dunia modern.

Dunia modern saat ini mengharuskan manusia untuk terus mengikuti perkembanganya. Arus globalisasi menyeret setiap orang ke dunia digital, dengan terminologi yang sering disebut virtual.
Tidak ada lagi batas waktu, 24 jam nonstop terhubung serta siap dihubungi. Semua serba terkoneksi, global, go internasional, dan instant culture. (Faisal, 2017) Hal tersebut tentu membuat dunia terkesan tanpa batas yang secara langsung maupun tidak langsung cukup berpengaruh terhadap adanya perubahan budaya di era generasi milenial saat ini.

Penelitian Heru Dwi Wahana menunjukka bahwa perubahan budaya tersebut ditandai dengan adanya sifat generasi milenial yang lebih terbuka terhadap berbagai akses informasi yang bersifat lintas batas, cenderung lebih permisif terhadap keanekaragaman, tidak perduli tentang privasi, dan bersedia untuk berbagi rincian intim tentang diri sendiri terhadap orang asing lewat media sosial. (Wahana, 2015)

Budaya membuat status merupakan aktivitas sehari-hari di media sosial, seperti di instagram, facebook, tweeter, dan media sosial lainnya. Trend, lifestyle menjadi arah tujuan hidup generasi milenial saat ini agar terlihat tampak dandy (sangat baik) dan serba terkini. Masing-masing individu dengan dunianya sendiri, padahal duduk berdampingan, namun hati, pikiran dan pandangan mata tertuju pada hasil teknologi yang berada di genggaman tangan masingmasing, yaitu berupa ponsel. (Walidah, 2017) Hal ini sesuai dengan penelitian yang dilakukan oleh Andreas Rudiwantoro yang 
menunjukkan bahwa generasi milenial memiliki kebiasan yang cukup khas, yaitu tidak bisa jauh dari gadget. Mulai dari bangun tidur sampai ingin tidur kembali gadget selalu ada di tangan, dan adapun ciri khas lain dari generasi milenial adalah sangat wajib memiliki media sosial. Hampir semua generasi milenial mempunyai akun media sosial, dan dengan akun tersebut, generasi ini dapat dengan mudah menunjukkan jati diri masing-masing kepada orang lain melalui status yang diupload (diungah). (Andreas, 2018)

Kini media sosial memiliki andil besar dalam mepermudah manusia untuk bersosialisasi dan berinteraksi, memungkinkan seseorang untuk berinteraksi dengan orang lain di seluruh dunia, menjalin pertemanan baru, berbisnis, dan bahkan mencari pasangan hidup. (Rafsanjani, 2018) Adapun sisi negatif dari media sosial adalah ketika warganet tidak bisa membedakan mana informasi yang benar dan teruji serta informasi yang tidak benar dan belum diketahui jelas asalnya, sebab saat ini dengan adanya media sosial yang semakin bebas, informasi yang masuk cenderung tidak terkontrol dan langsung diterima oleh masyarakat tanpa melalui proses filterisasi. Akses media sosial yang mudah, menyebabkan mudahnya pula peredaran berita bohong (hoax) di masyarakat.

Penelitian Iffah Al Walidah, menunjukkan bahwa berita hoax di media sosial beragam bentuknya; mulai dari aspek pendidikan, kesehatan, politik, serta ujaran kebencian, sehingga mengakibatkan pecahnya persatuan masyarakat yang telah dibangun dengan asas gotong-royong. (Walidah, 2017) Perkembangan budaya di era generasi milenial saat ini secara langsung maupun tidak langsung tentu cukup berpengaruh terhadap perubahan pola komunikasi dan juga perilaku generasi milenial saat ini. Terlebih, generasi milenial sudah pasti akan terjun ke berbagai bidang kehidupan di masyarakat, akan menghadapi berbagai perubahan dan berbagai macam orang, serta sangat mungkin akan menjadi pemimpin di masyarakat, oleh sebab itu perlu dibentengi dengan perilaku asertif.

Bagus Riono sendiri mengatakan bahwa perilaku asertif dalam perpektif psikologi Islam berkaitan erat dengan etika kita ketika seseorang berkomunikasi yaitu ma'ruf (baik), sadida (benar/jujur), karima (mulia), masyura (pantas), layyina (lemah lembut), dan baligha (berbekas/meninggalkan bekas). (Riyono, 2018)

Berdasarkan ulasan di atas, maka tulisan ini bertujuan untuk mengkaji lebih lanjut terkait tentang perilaku asertif generasi milenial dalam perspektif psikologi Islam, dengan menggunakan pendekatan studi pustaka (library research). Adapun data yang diperoleh bersumber dari bukubuku dan artikel jurnal yang terkait dengan 
perilaku asertif, generasi milenial dan juga psikologi Islam. Setelah data terkumpul penulis akan melakukan analisis data sehingga dapat ditarik sebuah kesimpulan yang merupakan tujuan dari penulisan artikel ini, yaitu untuk mendeskripsikan dan menjelaskan tentang perilaku asertif generasi milenial dalam perspektif psikologi Islam.

\section{PEMBAHASAN}

\section{A. GENERASI MILENIAL DAN PERILAKU ASERTIF}

Istilah generasi milenial memang sedang akrab diperbincangkan di era modern saat. Istilah tersebut berasal dari millennials yang diciptakan oleh dua pakar sejarah dan penulis Amerika, William Strauss dan Neil Howe dalam bukunya yang berjudul; Millennial generation atau generasi $\mathrm{Y}$ yang juga akrab disebut generation me atau echo boomers. Penggolongan generasi milenial bagi kedua penulis di atas adalah mereka yang lahir pada tahun 1980-an - 2000, (Republika, 2016) sedangkan Subhan Setowara mengatakan generasi milenial adalah mereka yang lahir antara tahun 1982-2004, (Setowara, 2018) Ruth N, Bolton mengatakan generasi milenial adalah meraka yang lahir antara tahun 1981-1990an, (Bolton, et al., 2013) dalam literatur lain dikatakan bahwa generasi milenial adalah mereka yang lahir antara tahun 1989 hingga 2004. (Faisal, 2017) Dari beberapa perbedaan pendapat di atas dapat ditarik sebuah kesimpulan bahwa generasi milenial adalah mereka yang lahir sejak tahun 1980an sampai dengan 2024, yaitu generasi muda saat ini yang berusia sekitaran 15-34 tahun.

Munculnya generasi milenial ditandai dengan meningkatnya penggunaan alat komunikasi, media dan teknologi informasi yang digunakan, seperti: internet, MP3 player, youtube, facebook, instagram dan lain sebagainya. Generasi milenial merupakan inovator, karena generasi ini berusaha mencari, belajar dan bekerja di dalam lingkungan inovasi yang sangat mengandalkan teknologi untuk melakukan perubahan di dalam berbagai aspek kehidupannya. (Moreno, Lafuente, Carreon, \& Moreno, 2017)

Generasi milenial adalah individu yang pandai bersosialisasi, terutama dalam komunitas yang diikuti, serta berkelana di media sosial. Generasi ini merupakan individu yang creative, biasa berpikir out of the box, selain itu merupakan orang yang percaya diri, berani mengungkapkan pendapat, serta tidak sungkan berdebat di depan publik. Generasi ini tumbuh besar dalam lingkungan budaya pop yang sudah mapan atau tersedia dengan baik di lingkungannya masing-masing, (Faisal, 2017) dalam hal ini teknologi menyediakan platform atau tempat untuk personalisasi dan memberikan kepuasan di semua aspek kehidupan. 
Gaye Ozcelik mengatakan bahwa generasi milenial memiliki tingkat kepercayaan diri dan kemandirian yang tinggi, individualistas, dan aktif secara sosial serta suka bekerja dalam tim. Milenial sendiri dianggap spesial karena generasi ini sangat berbeda dengan generasi sebelumnya, apalagi dalam hal yang berkaitan dengan teknologi. Generasi milenials memiliki ciri khas tersendiri yaitu, mereka lahir pada saat TV berwarna, handphone juga internet sudah diperkenalkan. (Ozcelik, 2015)

Tidak sedikit orang yang terlena terkena bius internet. Tidak jarang juga jika gadget tertinggal di rumah dan ia sudah dalam perjalanan ke sekolah atau pun kantor, ia rela kembali ke rumah untuk mengambilnya. Virus gadget dan internet rupanya telah berpengaruh pada perkembangan informasi dan komunikasi. Pemuda yang menyandang gelar generasi milenial telah akrab dengan gadget dan intenet sejak belajar di bangku sekolah dasar, (Walidah, 2017) sehingga generasi ini sangat mahir dalam hal teknologi.

Terlepas dari penjelasan di atas, terdapat beberap masalah yang dihadapi generasi milenial saat ini, seperti masalah self-esteem, bingung dengan berbagai kesempatan yang datang, minder sosial karena merasa tidak memiliki kelebihan, kecemasan terhadap penilaian sosial, keep up dengan kekinian, seperti; trend, lifestyle, dan informasi. (Faisal, 2017) Masalahmasalah tersebut tentu kalau tidak dibentengi dengan perilaku asertif akan berakibat fatal pada masadepan generasi milenial. Perilaku asertif akan memudahkan generasi ini dalam bersosialisasi dan menjalin hubungan dengan lingkungan, dimana kemampuan asertif akan menolong individu untuk mengungkapkan perasaan dan keinginannya secara langsung dan terus terang, pengungkapan asertif akan menghindarkan munculnya ketegangan dan perasaan tidak nyaman karena menahan dan menyimpan sesuatu yang ingin diutarakan. Perilaku asertif dapat digunakan untuk meningkatkan kemampuan kognitif atau kemampuan berpikir, memperluas wawasan, dan tidak mudah berhenti pada suatu yang tidak diketahui.

Perilaku asertif sendiri merupakan terjemahan dari ssertive behavior yang mengandung arti suatu tindakan atau perilaku yang dinyatakan dengan sopan untuk meminta seseorang berbuat sesuatu agar melakukan apa yang dikehendaki, meminta sesuatu pada orang lain disertai dengan sikap yang sopa sesuai dengan norma, tenang, dewasa, dan masuk akal. Baddel dan Lennox mengatakan bahwa asertifitas akan mendukung tingkah laku interpersonal yang secara simultan akan berusaha untuk memenuhi keinginan individu semaksimal mungkin dengan cara bersamaan juga mempertimbangkan keinginan orang lain, karena hal itu tidak hanya memberikan penghargaan pada diri 
sendiri tetapi juga pada orang lain. (Sriyanto, Abdulkarim, Zainul, \& Maryani, 2014)

Alberti dan Emmons menyatakan bahwa perilaku asertif adalah merupakan kemampuan seseorang untuk mengungkapkan yang paling diinginkan tanpa rasa cemas, mengekspresikan kejujuran dan melakukan hak-haknya tanpa melanggar hak orang lain, sedangkan menurut Rini, perilaku asertif adalah suatu kemampuan untuk mengkomunikasikan apa yang diinginkan, dirasakan dan dipikirkan kepada orang lain namun tetap menjaga dan menghargai hakhak orang lain, (Sriyanto, Abdulkarim, Zainul, \& Maryani, 2014) sedangkan Menurut Lioyd menyatakan bahwa perilaku asertif adalah perilaku bersifat aktif, langsung, dan jujur. Perilaku ini mampu mengkomunikasikan kesan respek kepada diri sendiri dan orang lain sehingga dapat memandang keinginan, kebutuhan, hak diri sendiri sama dengan keinginan, kebutuhan, dan hak orang lain pada saat berinteraksi. (Novalia, 2013)

Adapun aspek-aspek perilaku asertif yang dikemukakan oleh Alberti dan Emmons yaitu: (Sari \& Ayudya, 2015)

1. Mempreoritaskan kesetaraan dalam hubungan manusia, dalam hal ini menempatkan kedua belah pihak secara serata, memulihkan keseimbangan kekuatan dengan cara memberikan kekuatan pribadi terhadap yang lemah serta menjadikannya mungkin bagi setiap orang untuk menang dan tidak ada seorang pun yang merugi.

2. Bertindak menurut kemauan sendiri, dalam hal ini mengacuh kepada kesanggupan untuk membuat keputusan sendiri, terkait tentang karir, hubungan, gaya hidup, dan jadwal, untuk berinisiatif mengawali pembicaraan dan mengorganisir kegiatan, untuk mempercayai pilihan sendiri, untuk menetapkan tujuan, dan berusaha meraih itu semua, untuk meminta bantuan dari orang lain.

3. Mengekspresikan perasaan dengan jujur dan nyaman, dalam hal ini kesanggupan untuk kurang setuju, menunjukkan amarah, memperlihatkan kasih sayang atau persahabatan, mengakui rasa takut atau cemas, mengekspresikan persetujuan atau dukungan dari hak seseorang atau orang lain.

4. Menetapkan hak-hak pribadi, dalam hal ini kesanggupan sebagai warga negara, sebagai konsumen, sebagai anggota dari sebuah organisasi atau sekolah atau kelompok kerja, sebagai persiapan untuk menanggapi pelanggaran dari hak seseorang atau hak orang lain

5. Tidak menyangkal hak-hak orag lain, dalam hal ini mencapai ekspresi pribadi tanpa kritik tidak adil terhadap orang lain, tanpa perilaku yang menyakitkan terhadap orang lain, tanpa menjuluki, 
tanpa intimidasi, tanpa manipulasi, dan tanpa mengendalikan orang lain.

Dari uraian di atas dapat ditarik kesimpulan bahwa setiap individu memiliki hak dasar yang sama sebagai pribadi dan sebagai bagian dari kelompok sosial dalam mengemukakan pendapat, mengutarakan keberpihakan, serta mengungkapkan keinginan selama hal itu tidak merugikan pihak yang dituju dan demi kebaiakan kedua belah pihak. Oleh sebab itu perilaku asertif menjadi hal yang penting untuk diperhatikan dan diaplikasikan dalam kehidupan seharihari umumnya bagi setiap individu dan khususnya bagi generasi milenial saat ini.

\section{B. PERILAKU ASERTIF DALAM PERSPEKTIF PSIKOLOGI ISALM}

Psikologi Islam adalah usaha membangun sebuah teori dari khazanah kepustakaan Islam, baik dari Al-Qur'an, Hadis, atau kitab-kitab klasik yang ditulis oleh ulama-ulama Islam populer sehingga dapat mewarnai dunia psikologi modern saat ini. Adapun hal-hal yang dipelajari dalam ilmu psikologi Islam adalah mempelajari keunikan dan pola perilaku manusia sebagai ungkapan pengalaman interaksi dengan diri sendiri, orang lain, lingkungan sekitar dan alam kerohanian. (Sapuri, 2017) Zakiah Daradjat mendefinisikan psikologi Islam sebagai berikut: (Yudiani, 2013)

1. Psikologi Islam adalah ilmu yang berbicara tentang manusia, terutama kepribadian manusia yang bersifat filsafat, teori, metodologi dan pendekatan problem dengan didasari sumber-sumber formal Islam (Al-Qur'an dan Hadist), akal, indera dan intuisi.

2. Psikologi Islam merupakan konsep psikologi modern yang telah mengalami filterisasi dan di dalamnya terdapat wawasan Islam.

3. Psikologi Islam ialah perspektif Islam terhadap psikologi modern dengan membuang konsep-konsep yang tidak sesuai atau bertentangan dengan Islam.

4. Psikologi Islami adalah ilmu tentang manusia yang kerangka konsepnya benarbenar dibangun dengan semangat Islam dan berdasarkan sumber formal (AlQur'an dan Hadist) yang dibangun dengan memenuhi syarat-syarat ilmiah.

Dari definisi diatas dapat ditari kesimpulan bahwa psikologi Islam adalah ilmu yang membahas tentang corak psikologi berlandaskan citra dan perilaku manusia menurut ajaran Islam yang sesuai dengan tuntunan Al-Qur'an dan Hadis, dengan tujuan meningkatkan kesehatan mental dan kualitas keberagamaan manusia. (Yudiani, 2013)

Manusia adalah makhluk pilihan Allah yang mengembangkan tugas gandanya yaitu sebagai khalifah Allah dan abdullah (hamba) yang memiliki peran sebagai makhluk sosial dimana kualitas kemanusiaannya ditentukan oleh perannya 
dalam berkomunikasi dan berinteraksi dengan manusia lainnya. Islam menghendaki tercapainnya masyarakat damai yang dalam hal ini di dalamnya diwarnai dengan kasih sayang, oleh karena itu penekanan tingkah laku individu selalu dikaitkan dengan peranan sosialnya, yakni kualitas iman seseorang ditentukan oleh perilaku dan etika pergaulannya di masyarakat. (Muslim, 2009) Salah satu etika pergaulan dalam Islam adalah menerapkan perilaku asertif.

Perilaku asertif menurut Hamka adalah kebebasan seseorang ketika; (1) berkemauan (iradah). (2) menyatakan pikiran, dan (3) kebebasan jiwa dari keraguan, karena pada dasarnya manusia diberikan kebebasan secara fitrah oleh Allah Swtt dalam hal berpendapat. (Haris, 2010) Bagus Riono sendiri mengatakan bahwa perilaku asertif berkaitan erat dengan etika kita ketika berkomunikasi yaitu ma'ruf (baik), sadida (benar/jujur), karima (mulia), masyura (pantas), layyina (lemah lembut), dan baligha (berbekas/meninggalkan bekas), (Riyono, 2018) dalam hal ini mengatakan apa yang sebenarnya terjadi tanpa menyembunyikan maksud sehingga si komunikan paham apa sebenarnya tujuan dari si komunikator dalam menyampaikan pesan. Tidak perlu malu atau sungkan untuk mengakan yang sebenarnya, selama hal tersebut adalah suatu kebenaran, dan serta tidak ada pihak yang dirugikan dalam penyampaian pesan tersebut. (Al-Adawy \& Musthafa, 2009) Intinya perilaku asertif adalah jujur ketika mengkomunikasikan suatu pesan, dan tidak sampai menyinggung atau tidak ada maksud menyakiti perasaan orang lain.

Adapun adab-adab berperilaku asertif dalam perspektif psikologi Islam adalah sebagai berikau; (1) mengedepankan perdamaian, (2) menciptakan persaudaraan, (3) tidak menghina sesama, (4) menjauhi prasangka buruk terhadap orang lain, dalam hal mencari-cari kesalahan orang lain, dan menggunjing, (5) saling mengenal satu sama lain, (6) berkasih sayang terhadap sesama, dan (7) berbuat baik, berkata jujur serta berlaku adil terhadap sesama. (Pranato, 2016) Dalam berperilaku asertif, seseorang dituntut untuk jujur terhadap diri sendiri dan jujur pula dalam mengekspresikan perasaan, pendapat dan kebutuhan secara proporsional, tanpa ada maksud memanipulasi, memanfaatkan ataupun merugikan pihak lain ketika dalam menyampaikan pesan. (Anfajaya, 2016)

Perkataan demi perkataan yang keluar dari mulut harus selalu tertata dan kemurahan hati terhadap orang lain menjadi salah satu poin penting dalam berperilaku asertif menurut psikologi Islam, (AlHasyim, 2013) hal ini disebutkan pula dalam Qur'an Surah An-Nahl / 16 : 125, Allah berfirman sebagai berikut: 
"Serulah (manusia) kepada jalan Tuhan-mu dengan hikmah dan perkataan yang baik dan bantahlah mereka dengan cara yang baik. Sesungguhnya Tuhanmu Dialah yang lebih mengetahui tentang siapa yang tersesat dari jalan-Nya dan Dialah yang lebih mengetahui orang-orang yang mendapat petunjuk".

Penegasan ayat tersebut mengisyaratkan kepada manusia agar bersikap tegas dalam hal kebenaran, berkata jujur, terbuka, dan harus didasari dengan kasih sayang (silaturahim) yang dalam hal ini mempunyai makna tidak hanya sekedar saling bertegur sapa, menyampaikan pendapat, namun juga menyiarkan amanat Allah dalam hal keadilan dan pemerataan sosial diantara manusia di lingkungan manapun, khususnya di era generasi milenial saat ini, (Sundary, 2002) oleh sebab itu perlunya perilaku asertif ditanamkan dalam diri generasi milenial saat ini dengan berpedoman pada tuntunan-tuntunan Islam yang sudah penulis jelaskan sebelumnya.

\section{KESIMPULAN}

Dalam perspektif psikologi Islam, perilaku asertif menuntut individu, khususnya generasi milenial saat ini untuk berani berkata 'iya' apabila individu tersebut mau, dan berani berkata 'tidak' kalau memang individu tersebut tidak mau", dalam hal ini ketegasan sebagai pembelaan atas hak-hak pribadi, ekspresi pikiran, perasaan, dan keyakinan secara langsung, jujur, serta pantas untuk menghormati hak- hak orang lain. Generasi milenial tidak perlu malu atau sungkan untuk mengakan yang sebenarnya selama itu tentang kebaikan atau kebenaran. Dalam mengkomunikasikan suatu pesan, generasi milenial harus bersikap ma'ruf (baik), sadida (benar/jujur), karima (mulia), masyura (pantas), layyina (lemah lembut), dan baligha (berbekas/meninggalkan bekas dalam jiwa, mengatakan apa yang sebenarnya terjadi tanpa menyembunyikan maksud. Jadi perilaku asertif menuntut generasi milenial saat ini untuk bisa menyatakan pesan dengan tegas dan berani tanpa terhalangi rasa hormat yang berlebihan selama maksud yang disampaikan baik dan demi kebaikan lawan komunikan.

\section{DAFTAR PUSTAKA}

Al-Adawy, \& Musthafa, S. (2009). Fikih Akhlak. Yogyakarta: Qisthi Pers.

Al-Hasyim, A. M. (2013). Akhlak Rasul Menurut Bukhari Muslim . Jakarta: Gema Insani.

Anastacio, \& Zelia. (2016). Self-Estem, Asertiveness and Resilience in Adolescents. International Journal of Psicologia, Vol. 321.

Andreas, R. (2018). Langkah Penting Generasi Milenial Menuju Kebebasan Finansial Melalui Investasi. Vol. 05 No. 01 .

Anfajaya, M. A. (2016). Hubungan Antara Konsep Diri Dengan Perilaku Asertif Pada Mahasiswa Organisatoris Fakultas Hukum Universitas Diponegoro Semarang. Vol. 5 (3.

Bolton, R. N., Parasuraman, A., Hoefnagels, A., Migchels, N., Kabadayi, S., Gruber, T., et al. (2013). Understanding Generation $\mathrm{Y}$ and 
Their Use of Social Media: A Review and Research Agenda. Internationl Journal of Service Management, Vol. 04.

Dewi, \& Karlina. (2017). Pengaruh Layanan Bimbingan Kelompok Dengan Teknik Sosiodrama Terhadap Perilaku Asertif Siswa Di SMP Negeri 5 Padaherang, Sukanagara, Pangandaran, Indonesia. Vol. 9-14.

Faisal Muhammad. (2017). Generasi Phi П;

Memahami MIlenial Mengubah

Indonesia. Jakarta: Republika

Penerbit.

Faisal, M. (2017). Generasi Phi $\Pi$; Memahami Milenial Mengubah Indonesia. Jakarta: Republika Penerbit.

Haris, A. (2010). Etika Hamka . Yogyakarta: PT. LkiS Priminting Cemerlang.

Moreno, F. M., Lafuente, J. G., Carreon, F. A., \& Moreno, S. M. (2017)., The Characterization of the Millennials and Their Buying Behavior. International Journal of Marketing Studies, Vol. 9, No. 5.

Muslim, N. (2009). Moral Dan Kognisi Islam. Bandung: CV Alfabeta.

Novalia. (2013). Perilaku Asertif Dan Kecenderungan Menjadi Korban Bullying. Jurnal Ilmiah Psikologi Terapan, Vol. 01, No. 01.

Ozcelik, G. (2015). Engagement and Retention of the Millennial Generation in the Workplace through Internal Branding. International Journal of Business and Management, Vol. 10, No. 3.

Pranato, A. (2016). Etika Pergaulan Dalam Al-Qur'an Dan Implikasinya Terhadap Pembelajaran PAI Di Sekolah. Vol. 03, No. 02.

Rafsanjani, B. (2018). Sikap Tabayun Dalam Al-Qur'an Menurut Mufassir dan Kontekstualisasi Pada Problematika Pemberitaan Media Sosial. Surabaya: Universitas Negeri Sunan Ampel.
Republika, D. P. (2016, Desember). Koran. Retrieved 2018, from Mengenal Generasi Milenial.

Riyono, B. (2018). Perilaku Asertif Generasi Milenial Dalam Perspektif Psikologi Islam. Seminar Psikologi. Universitas Ahmad Dahlan (Yogyakarta).

Sapuri, R. (2017). Psikologi Islam; Tuntutan Jiwa Manusia Modern. Jakarta: Rajawali Pers.

Sari, \& Ayudya, P. N. (2015). Hubungan Antara Peilaku Asertif Dengan Penyesuaian Diri Pada Siswa Kelas X SMK Kristen Salatiga. Psikologi.

Setowara, S. (2018). Muslim Milenial; Catatan dan Kisah Wow Muslim Zaman Now. Yogyakarta: PT Mizan Pustaka.

Sriyanto, Abdulkarim, A., Zainul, A., \& Maryani, E. (2014). Perilaku Asertif dan Kecenderungan Kenakalan Remaja Berdasarkan Pola Asuh dan Peran Media Massa. Jurnal Psikologi, Vol. 41, No. 01.

Sundary, R. I. (2002). Makna Silaturahim Dalam Membangun Lingkungan Kerja Yang Demokratis Di Perguruan Tinggi. Vol. XVIII No. 2.

Suryanoto. (2015). Self Disclosure, Perilaku Asertif Dan Kecenderungan Terhindar Dari Tindakan Bullying. Jurnal psikologi, Vol. 04, No. 02.

Wahana, H. D. (2015). Pengaruh Nilai-Nilai Budaya Generasi Milenial dan Budaya Sekolah Terhadap Ketahanan Individu (Studi Di SMA Negeri 39, Cijantung, Jakarta). Vol. 14-22.

Walidah, I. A. (2017). Tabayyun Di Era Generasi Millenial. Vol. 2 Nomor 01 .

Yudiani, E. (2013). Pengantar Psikologi Islam. Vol. 175-186 . No. 02 . 